\section{階段室型共同住宅における大規 模改修手法の研究}

ーコーシャハイム千歳烏山住棟改善モ デル事業を通じて（その 1 ) -

\section{A STUDY ON LARGE-SCALE RENOVATION METHOD FOR STAIRCASE TYPE RESIDENTIAL BUILDING}

\section{- Through the case of KOSHAHEIM} CHITOSEKARASUYAMA renovation project Part 1 -

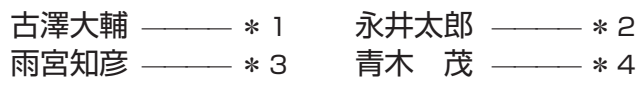

キーワード :

再生建築，階段室型共同住宅，団地，改修，ストック活用，

耐震補強

Keywords:

Restored Architecture, Staircase type residential building, Public housing, Renovation, Stock management, Seismic strengthening

\section{Daisuke FURUSAWA - *1}

Tomohiko AMEMIYA — $* 3$

There is a lot of dilapidated building stock of staircase type residential building which is over 30 years after construction. It has been becoming urgent issue how to regenerate these old stocks.

This study is aimed to propose a versatile renovation method for staircase type residential building. Here we report 1) the technical review process for building upgrade, and 2) many variation of room types which accepts diversity of residents. Both verification reports are on the case of large-scale renovation project by Tokyo Metropolitan Housing Supply Corporation.

\section{1. 研究の背景と目的}

現在国内には、築 30 年以上を経て老朽化した階段室型共同住宅 （以下、階段室型）のストックが大量に存在する。公的な賃貸住宅 全体においては (注 1 、 300 万戸を超える総ストック戸数のうち、約 半数が 3〜 5 階の中層階段室型であり、総じてこれらの公共性の高い 住宅ストックへの対応は、建替え中心から大規模改修 (注 2) などの既 存建築を利活用する取り組みが必要になることが予想されている ${ }^{1)}$

東京都住宅供給公社（以下、JKK 東京）が管理する賃貸住宅にお いても、約 6 割が階段室型であり、これらをどのように再生するの かが喫緊の課題となっている（図 1)。

階段室型の改修はこれまで多くの実施事例があり、またその実態 に関する研究もいくつか行なわれている。しかし、エレベータや共 用廊下など、建築を構成する部位に限定した研究事例か、解体を前 提とした技術的な検証実験に留まっており、住棟全体の平面計画、 構造計画、設備計画に対して複合的に検討を行なった事例は少ない 2)374)5)。さらに、現行法規に適合させる為の法的スキームを整理し、 現場段階での施工状況を詳細に記録するなど、総合的な検討を重ね、 実際の居住の用途に供した大規模改修事例は極めて少ない(注3)。

本研究は、階段室型における汎用性の高い改修手法を提示するこ とを目的とし、本稿では 1) バリアフリー化や耐震補強、設備更新 など既存建物の性能を向上させる技術的検討、2) 多様な住み手を想 定した住戸計画の 2 点に関して報告する。次稿では 3）安全性を証 明する為の法的スキーム、4）施工記録の作成方法に関する報告を行 なう。いずれも、JKK 東京が実施した大規模改修の検証報告である。

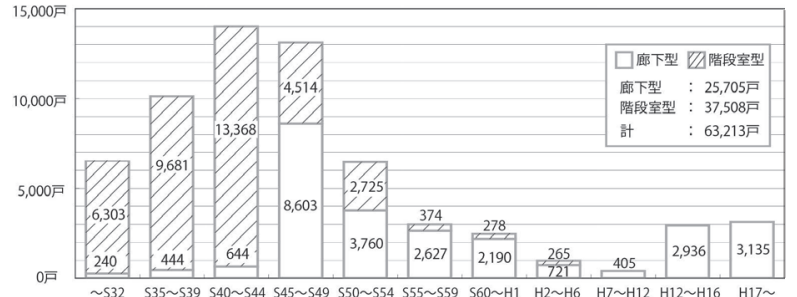

図1 東京都住宅供給公社建設年代別管理戸数

\section{2. 計画の概要}

コーシャハイム千歳烏山は、旧烏山住宅(注4) を再整備した計画で、 8 棟の一般賃貸住宅と 2 棟のサービス付き高齢者向け住宅、 1 棟の保 育所やクリニックを含む併設施設、老朽化した中層階段室型を大規 模改修した住棟改善モデル事業 (以下、モデル事業) 1 棟の計 12 棟、 599 戸を 3 期にわたって供給したものである（図 2)。

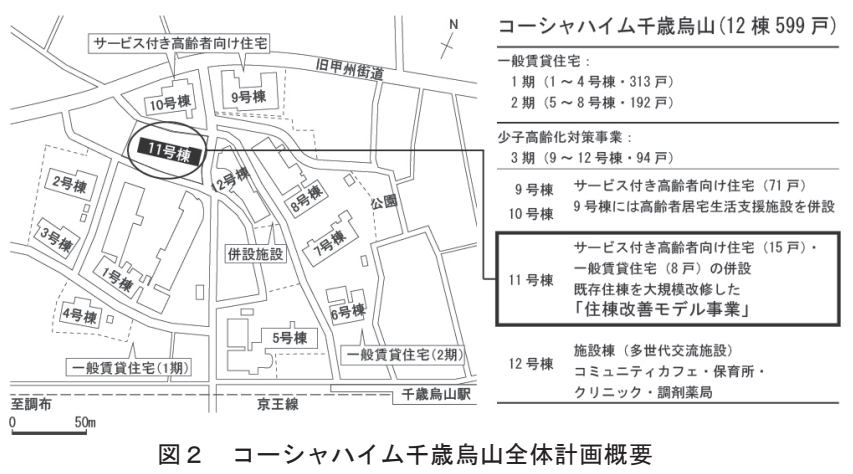

\footnotetext{
日本大学理工学部建築学科 助教・修士 (工学)

（干 101-8308 東京都千代田区神田駿河台 1-8-14）

東京都住宅供給公社 学士 (工学)

千葉大学大学院工学研究科 特任研究員・修士 (環境学)

首都大学東京都市環境学部 特任教授・博士 (工学)
}

Assist. Prof., Dept. of Architecture, College of Science and Technology, Nihon Univ., M. Eng.

2 Tokyo Metropolitan Housing Supply Corporation, B. Eng.

Project Researcher, Dept. of Graduate School and Faculty of Engineering, Chiba Univ., M. Env.

4 Research Prof., Dept. of Architecture and Building Engineering, Tokyo Metropolitan Univ., Dr. Eng. 


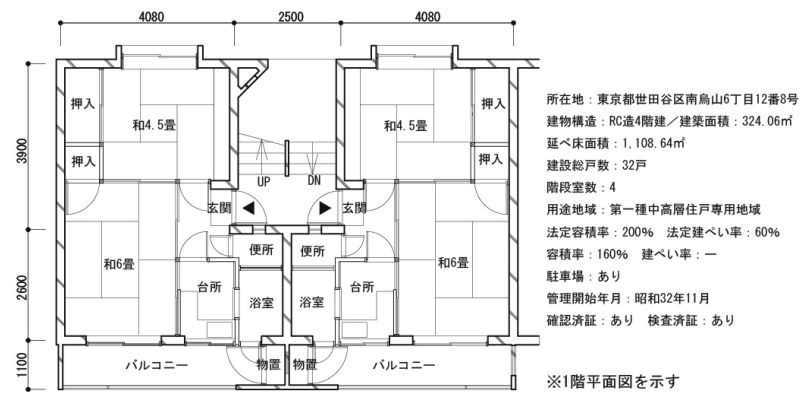

図 3 既存住戸平面図

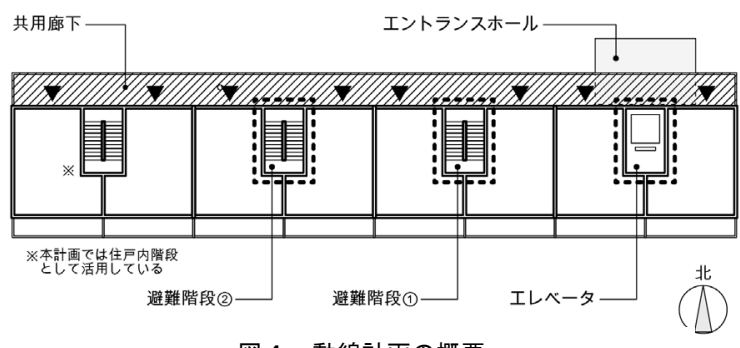

図 4 動線計画の概要

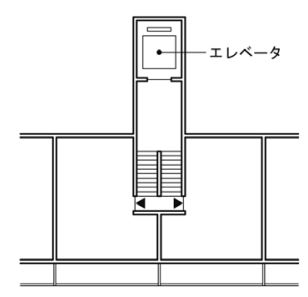

図 5 階段室型エレベータ

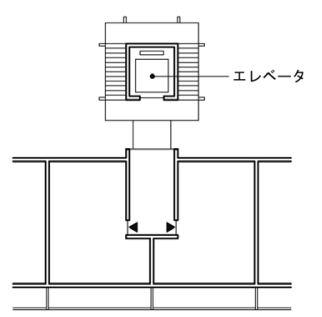

図 6 階段一体型エレベータ

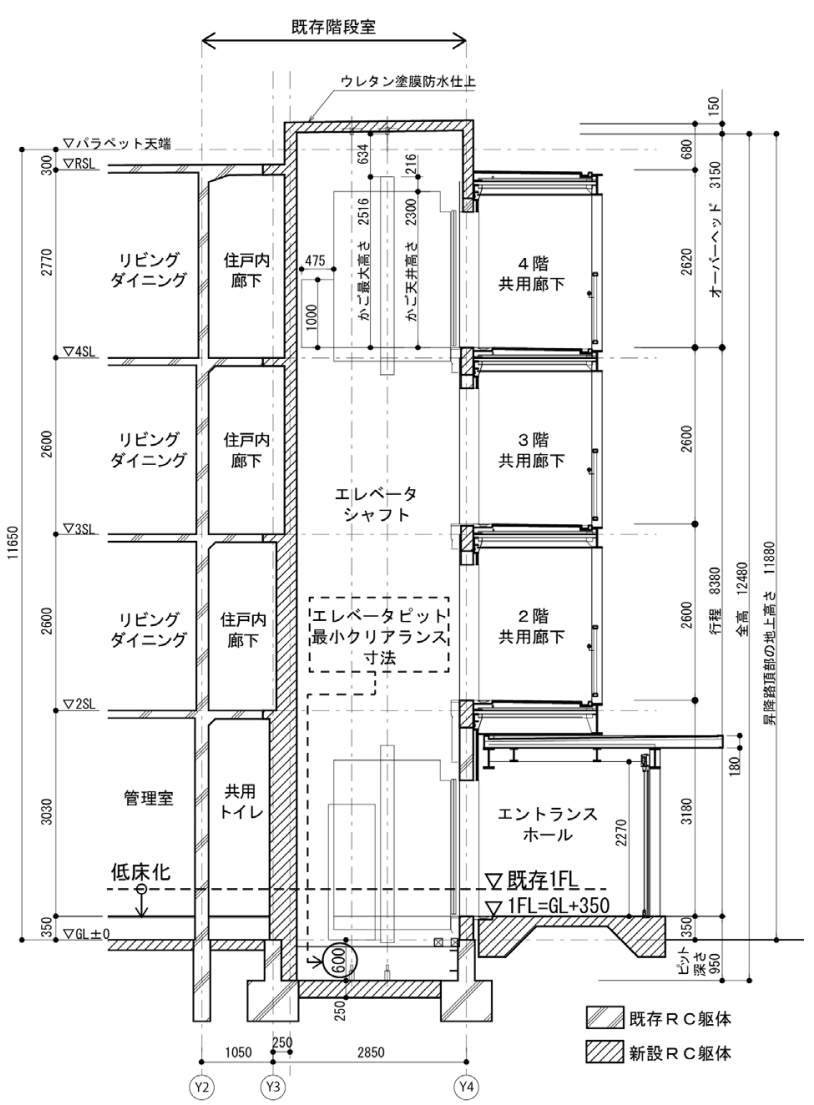

図 7 エレベータシャフト断面図
このうちモデル事業は、JKK 東京が所有する中層階段室型ストッ クの活用に向けて、今後の大規模改修手法の確立が求められた実証 事業として位置付けられており、今回の研究対象である。なお、モ デル事業完了後、全住戸が居住の用途に供されている。

モデル事業の既存建物となった昭和 32 年竣工の 4 階建て階段室型 は、JKK 東京が所有するストックの中で最も築年数の古いものに属 する (図 3)。耐震補強、設備系統の更新、そして階段室型のアクセ シビリティを高める動線計画など、既存建物の性能を向上させるこ とはもとより、居住ニーズの変化を踏まえた多様な住戸プランを用 意し、賃貸住宅としての市場的価值を高めることが、モデル事業の 目標として掲げられた。

\section{3. 動線計画}

バリアフリー化を実現する為の「エレベータ」と「共用廊下」、安 全性を確保する為の「避難階段」セキュリティラインを明確化する 「エントランスホール」の 4 項目を付加改修した。各項目に対し、 汎用性を軸に検討を行なった結果、エレベータと避難階段は既存階 段室を転用し、共用廊下とエントランスホールは住棟北側へ増築す る計画となった（図 4)。各項目の検討概要を以下に示す。

\section{(1) エレベータ}

階段室型へのエレベータ付加改修手法は、住棟外部に増築するも の、既存階段室の階段を解体し、エレベータシャフトに置換するも のの 2 つに大別できる。このうち外部への増築は、辻ら ${ }^{2)}$ が詳細な 分析を行なっている。この中で述べられている「階段室型エレベー 夕」（図 5）は、既存住棟への工事介入が少ない、居住者が住みなが ら施工できる、工事費が比較的安価であるなどの長所があり、多く の事業主体で採用実績がある。しかしエレベータ着床階と既存階段 室とが半階ずれる為、完全なバリアフリーにならないことが最大の 久点となっていた。それを解消する為に考案された小川ら 3)4)の「階 段一体型エレベータ」（図 6) は、バリアフリーを達成できるものの 設置費用が高額になるという問題と、1 住棟に付き複数のエレベー タが必要になることによるランニングコストの問題が課題として残 っている。また、エレベータシャフトを外部に増築する為、敷地内 余地の必要性、日影・道路斜線規制といった集団規定へ抵触する可 能性など、敷地条件に左右されることが特に問題となる。本研究に おいては、他の敷地一の応用可能性を考慮し、住棟外部一増築する のではなく、既存階段室の 1 つをエレベータシャフトへ置換する方 法を選択した。

一般的に階段室型は 1 階床レベルが比較的高く設計されている場 合が多いが、バリアフリーの観点に立てば、1 階床レベルを極力地 盤面に近づけるのが好ましい。そこで本研究では、1 階住戸を低床 化 (注5) 寸る為、置換したエレベータシャフトのピットにおいてエレ ベータの底面が、既存基礎フーチングと干渉しない最下限のレベル を基準として、1 階床レベル (注6) の設定を行なった（図 7、8）。

\section{（2）共用廊下}

1 つのエレベータで全住戸への効率的なアクセスを可能にする為 には、片廊下型の共用廊下を設けることが合理的である。その付加 方法は、住棟外部に自立した構造体として増築し、連絡通路などで 
建物本体に接続させるもの、既存躯体と一体化して増築するものの 2 つに大別される。前者の場合、塔状比の規定を満たしたうえで、 廊下幅の拡張や柱梁のアウトフレーム化など、安定して自立するこ とが可能な構造体とすることが必要になり、敷地内余地の不足、建 設コストの増加が懸念される。さらに、エレベータ同様、集団規定 一の抵触可能性を考慮する必要がある為、一体化増築にて鉄骨造の 廊下を付加することが妥当と判断した。

廊下幅員は、共同住宅における面積算定緩和が適用される最大幅 の $2 \mathrm{~m}$ とし、法定床面積 $0 \mathrm{~m}^{2}$ の増築と位置付けることで、既存不適格 部分が現行基準の遡及を受けない計画とした (注7)。

既存外壁と廊下との接合部分は、外壁の不陸を想定したディテー ルとする必要がある為、鉄骨階段を支持する桁 $(C-125 \times 65 \times 6 \times 8)$ を外壁に添わせ、桁が接触する部分の既存モルタルをはつった上で 通しボルトで挟み込み、躯体に固定している。通しボルトは@800で まんべんなく設置することで、躯体一水平荷重が均一にかかるよう にした。また、桁と躯体との間にはクリアランスを設け、無収縮モ ルタルおよびエポキシ樹脂を充填することで不陸の吸収を行なって いる（図 9）(写真 1)。

\section{（3）避難階段}

避難階段の設置方法は、住棟外部に増築するものと既存階段室を 転用するものがあるが、先の 2 項目と同様、集団規定などへの影響 を考慮し、外部増築の方法は採用していない。

既存階段室を避難階段に転用寸る際、新設する共用廊下と既存階 段の踊場が半階分ずれて接触することに注意を要する。本研究では、 既存階段の上り終わり地点と共用廊下とを通路を設けて接続させる 案（通路案）と、既存階段を解体し、上る向きを反転した鉄骨階段 を新たに階段室内に設置する案（反転案）に対して検討を行なった (図 10)。

通路案は既存階段をそのまま流用することによる工期短縮、コス 卜軽減などが利点であるが、通路の分だけ専有面積が減少し、賃料 収入に影響が出てしまうという久点がある。一方で反転案は、共用 廊下からスムーズにアクセスできるという利点があるが、解体部分 や新設階段の施工手間による建設コストの増加が欠点として挙げら れる。そこで、両案のイニシャルコスト及びランニングコストを見 込んだ事業性を具体的に比較し、優位性が確認された通路案を採用 した。なお、既存階段室 2 ケ所に対して通路案を適用することで、 共同住宅としての避難キャパシティを向上させている。

\section{(4) エントランスホール}

階段室型は、階段が直接外部に面していることから、居住者以外 の人が自由に入れてしまうセキュリティ上の問題を有している。そ こで本研究では、1 階共用廊下を手摺で囲み、エレベータの出入り 口に隣接寸るようにエントランスホールを設け、セキュリティライ ンの明確化を行なった。なお、エントランスホールは、入居者数に 応じた広さを確保する必要性から、既存躯体外部にエキスパンショ ンジョイントで構造的に分離した形で増築している(注 ${ }^{8)}$ 。

共用廊下とエントランスホールは、増築に対する法的位置付けが 異なるため (注 9)、2 階共用廊下の床スラブとエントランスホールの 屋根スラブは明確に分離させる必要がある。また、スラブ同士の干
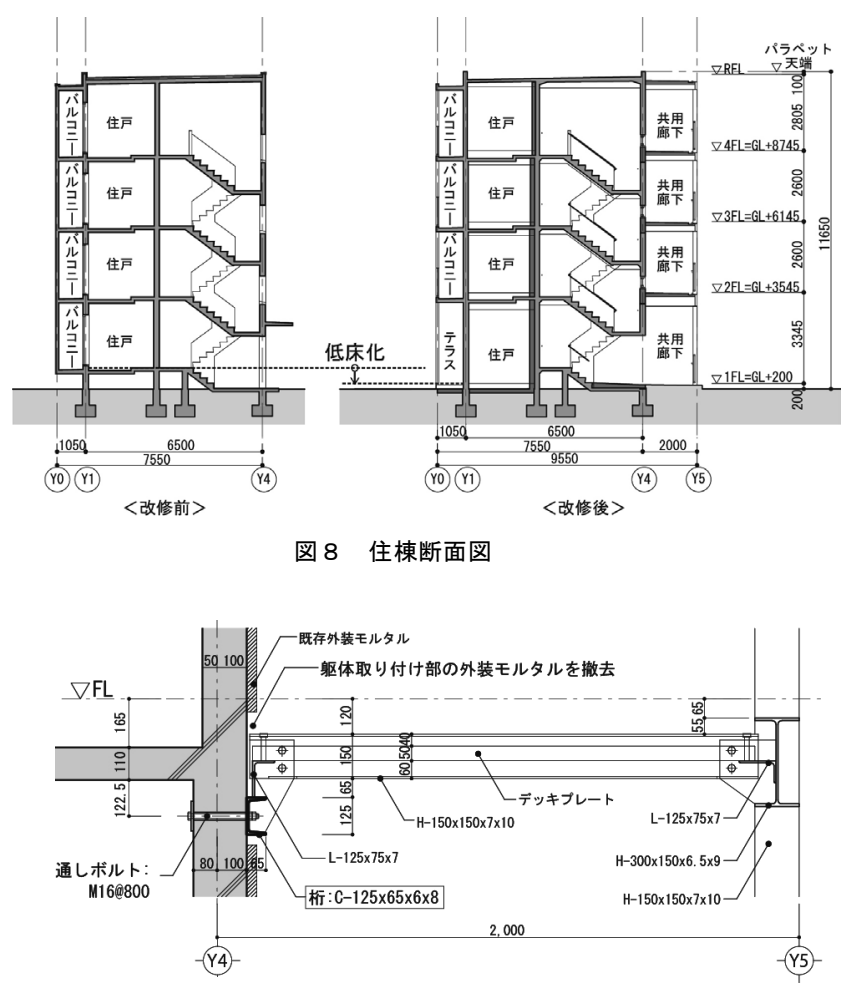

図 9 共用廊下接合部詳細図

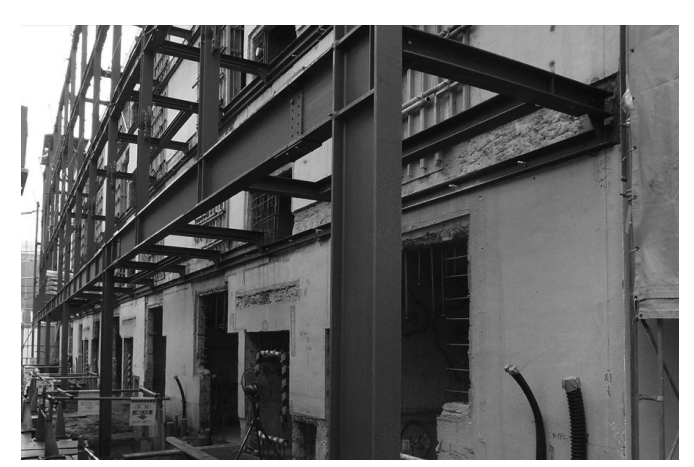

写真 1 共用廊下施工状況

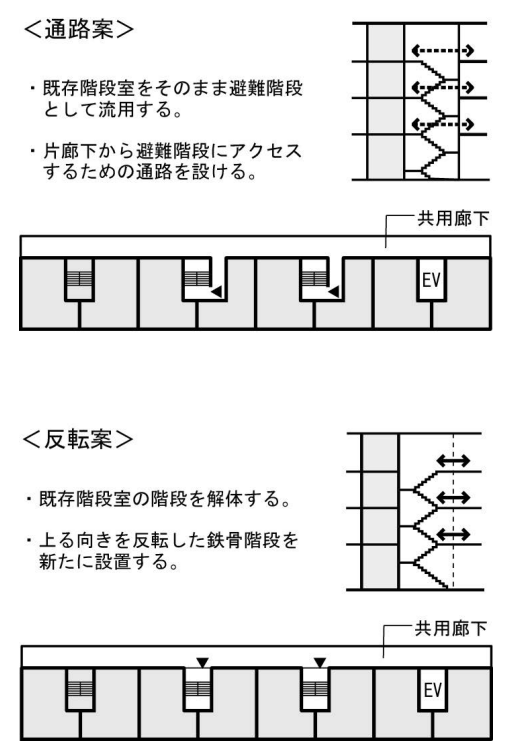

図10 避難階段検討図 


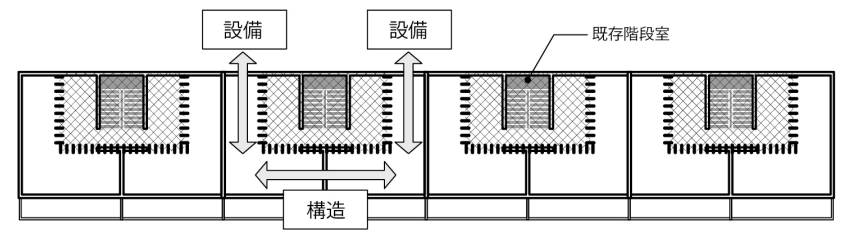

階段室型コアを示す

図 11 階段室型コア概念図

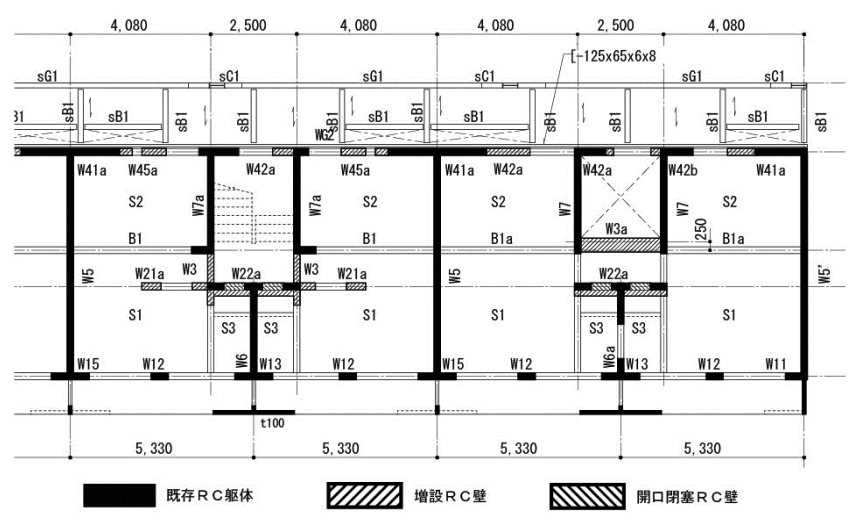

図 12 構造計画図

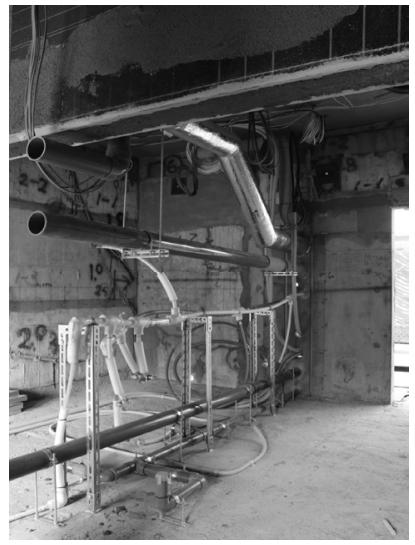

写真 2 設備壁の施工状況

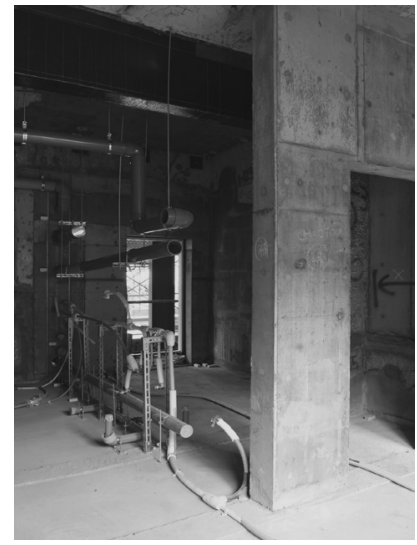

写真 3 階段室型コアを形成する 補強壁と設備壁

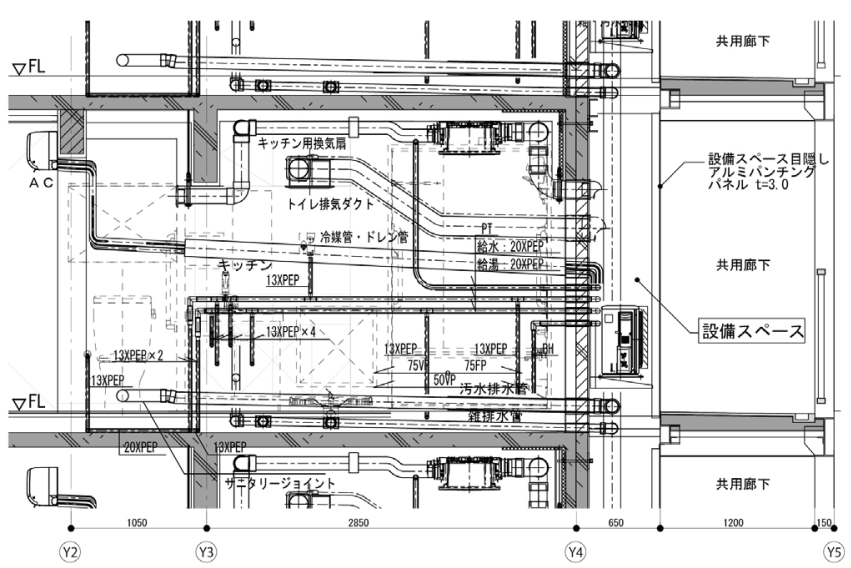

図 13 設備壁断面詳細図
渉を避けることで、エントランスホールの天井高さが十分に確保で きなくなる可能性を考慮し、低床化による 1 階床レベルの設定と併 せて検討する必要があることに注意する（図 7）。

\section{4. 階段室型コアの形成}

階段室型は、建設された年代によって階段幅や階高、住戸面積に 寸法の差異が存在するものの、2 つの住戸で共有する階段室が反復 する平面形式を有する。

本研究では、階段室型ストックの建設年代を問わず、幅広く応用 可能な汎用性の高い改修手法を確立する為、既存の階段室を取り囲 むように、耐震補強の為の RC 壁、住戸内の設備配管を内包する乾式 壁をそれぞれ間口方向、奥行方向に配置し、既存階段室が拡張した ような形のコアを形成している（以下、階段室型コア）。既存の平面 形式を受け継ぐこの階段室型コアは、動線以外に構造的、設備的な 機能を担うことになる為、オフィスビルにおけるコア計画に相当す る、改修計画上の重要な糸口になるものと考える（図 11）。

\section{5. 構造計画}

階段室型は、一般的に小規模な住戸単位が連続する RC 壁式構造で ある為、奥行き方向の壁量は戸境壁により充足されている。よって、 耐震補強を行なう場合、間口方向に対して補強の壁を配置するのが 効果的である。本研究では、階段室型コアの間口方向に添う形で、 耐震補強を目的とした $200 \mathrm{~mm}$ 厚の RC 壁(以下、補強壁)を増設した。

住戸玄関の新設などで一部解体される共用廊下側の壁面量が、補 強壁により住棟中央部に過不足無く補われることで、バルコニー側 と共用廊下側の開口率の差によって生じていた偏心率の低減が図ら れた、バランスの良い構造計画となっている（図 12）。

既存躯体に設けられていた換気空や設備配管用のスリーブは全て 開口閉塞を行ない、構造耐力向上に寄与させている。閉塞部の躯体 と既存躯体との接続は、接着系アンカーによる方法と、新規の鉄筋 を溶接する方法の 2 通りにて行ない、既存躯体の劣化状況に適宜対 応できる施工計画とした。なお、一体化増築した共用廊下の加重を 含めた改修後の耐震診断により、構造耐力の性能を示寸指標のひと つである IS 值が、判定基準值を超えることを確認している。

\section{6. 設備計画}

改修後においてもサステナブルな運用を可能にする為に、上下階 を縦断するパイプスペースは専有部内部に設けずに、共用廊下に面 して縦配管類をまとめた設備スペースを確保した。また、原則的に 室外機や給湯器、電機、ガス、水道などのメーター類も全てこの設 備スペースにまとめて配置し、外部から容易にメンテナンスができ るような計画としている。

住戸内には、壁状の設備配管用スペースを乾式工法で設置した(以 下、設備壁)。設備壁は階段室型コアに添う形で奥行き方向に展開さ せ、共用廊下に設けられた設備スペースと最短経路で接続する。換 気ダクトや給排水管、エアコンの冷媒・ドレイン管、ガス配管、電 気配線など、住戸内の設備上必要になる配管類はす心゙てこの設備壁 内を経由している。既存の梁にスリーブを設けずに、立体的に配管 を処理することができる為、既存躯体の状況に左右されない設備計 画が可能になっている。特に既存躯体の階高に制約があり、住戸内 
の天井や床の懐を十分に確保できない階段室型の改修に有効な設備 計画と考えられる（図 13）（写真2、3）。

\section{7. 住戸計画}

サービス付き高齢者向け住宅を取り入れ、共用リビングルームをエ ントランスホールに隣接させるなど、居住者間での交流を促す場所を 用意した。また、居住ニーズの変化に対応した貨貸住宅となるよう、 全ての住戸の間取りを一新した。間取りを更新する際に、通常、既存 躯体の解体や壁の新設など、壁の配置変更が必要になる。本研究では、 階段室型コアを形成する補強壁と設備壁によって間取りの骨格を構 成することで、解体や新設を最小限に抑えつつ、多様な間取りを実現 させている。

キッチンや洗面トイレ、洗濯機等住戸内の設備機器は、全て設備壁 に取り付くように配置し、コンパクトな住戸内動線を実現した。特に 高齢者住宅においては、半身麻瘏の病状などに対応できるように、利 腕のみで機器に触れられる、一筆書きの動線計画となっている (注 10)

(図 14)。また、既存住戸の1スパンをそのまま利用した住戸以外に、 2 スパンを 1 つの住戸に割り当てた「2 戸 1 住戸」、3 スパン分を 2 戸 に分けた「3 戸 2 住戸」、既存階段室を専有部内に取り込んだ「メゾ ネット住戸」など、面積や高さに変化を与えた 12 種類の住戸バリエ ーションを実現した（図 15、16)。また、既存階段室の多様な活用方 法を試みる為、メゾネット住戸は、上下階に垂直に重なるものと対角 線上に重なるものの 2 種類を設けた。低床化された 1 階部分の住戸は、 南側に専用庭を持ち、 $2700 \mathrm{~mm}$ の十分な天井高さを確保している。

\section{8. まとめ}

今回の研究で得られた具体的な成果は以下の通りである。

1）動線計画上重要になる「エレベータ」、「共用廊下」、「避難階段」、 「エントランスホール」の各項目を付加改修する際の、検討プロ セスを提示することが出来た。

2）「階段室型コア」という動線、構造、設備、住戸の各計画を複合 的に検討する際の、基礎となる概念を提示することが出来た。

3）構造及び設備計画において、「補強壁」「設備壁」という階段室型 の改修に有効である、具体的な手法を提示することが出来た。

4）住戸面積や天井高さに変化を与えた多様な間取りによる、居住二 ーズの変化に対応可能な住戸計画を提示することが出来た。

\section{付記}

本研究は、首都大学東京リーディングプロジェクトにおけるリフ アイニング建築開発プロジェクト研究の成果として位置付けられて いる（写真 4、5）。JKK 東京では、首都大学東京と「リファイニング 建築開発プロジェクト」の連携協定書を締結し、共同研究として、 コーシャハイム千歳烏山において住棟改善モデル事業を実施した。

\section{注釈}

1）公的な賃貸住宅とは、公営住宅の他に、地方住宅供給公社および都市再生 機構が管理する賃貸住宅を指す。

2）本稿における大規模改修とは、老朽化した既存建物を社会的要請や現行法 規に適合させるために施す、複合的な改修のことを指す。

3）先例としてルミナスコート壱番館（設計・監理：青木茂建築工房、2009 年竣工）がある。

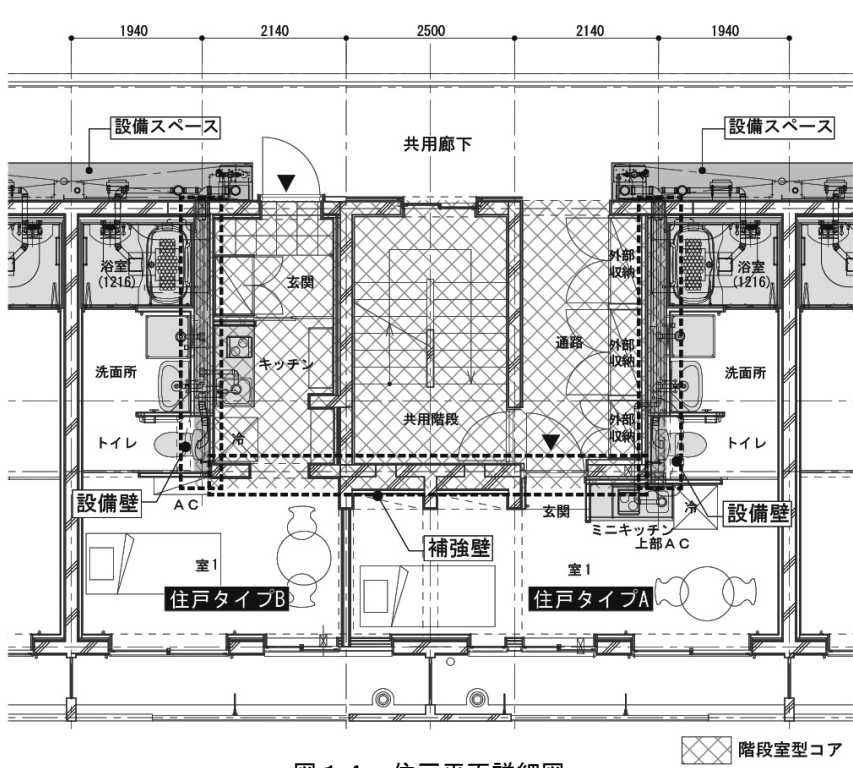

図 14 住戸平面詳細図

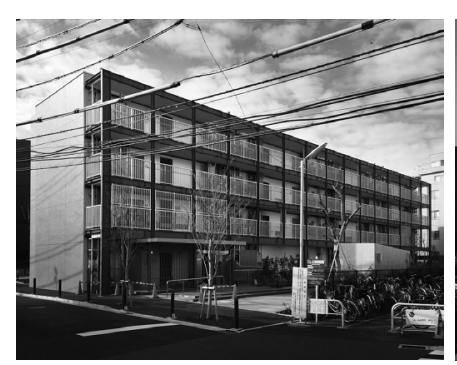

写真 4 竣工写真（北側外観）

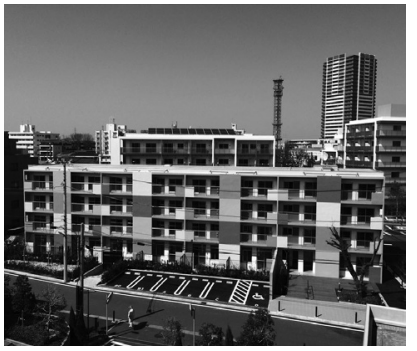

写真 5 竣工写真（南側外観）
4）旧烏山住宅は、昭和 31〜32 年にかけて建設された 4 階建て階段室型 21 棟、計 584 戸からなる一般賃貸住宅である。モデル事業の対象となった 1 棟を除き、建替えによりコーシャ八イム千歳烏山へと再整備された。

5）階段室型における 1 階住戸の床スラブは、一般的に RC ではなく木造とな っている。木材の腐食が懸念されること、木造ゆえに解体費が比較的安価 であること、住戸の天井高さが確保できること、そして外構レベルとの段 差を処理するスロープ面積を抑えられることなどの点も、低床化する為の 動機付けになっている。

6) 改修前の既存 1 階床レベルが GL+700mm であったのに対し、改修後のエン トランスホールの 1 階床レベルは GL+350m 、住戸の 1 階床レベルは GL $+200 \mathrm{~mm}$ である。なお、エントランスホールと 1 階住戸のレベル差は、 共用廊下に設けたスロープで吸収している。

7）現行法規が改修における様々なケースに充分対応できるよう柔軟に整備 されていないなかで、建物の安全性の証明と計画の合理性を共に満たすよ うな計画のスキームをデザインすることが設計者には求められる。なおス キームに関する詳細な報告は次稿にて行なう。

8）敷地内に増筑する余地を必要とする為、計画地ごとに検討を要することに なるが、斜線規制などの集団規定には抵触していない。

9）１階エントランスホールの屋根スラブはエキスパンションジョイントに よる増築であるのに対し、2 階共用廊下の床スラブは一体化増築となって いる。もし、共用廊下の床スラブに、エントランスホールの屋根スラブと しての役目を担わせた場合、廊下以外の用途が発生し、共用廊下が、面積 算定緩和を適用した法定床面積 $0 \mathrm{~m}^{2}$ の増築とみなされない可能性がある。 その場合、既存不適格部分が現行基準の遡及を受けることになる恐れがあ る為、両スラブは明確に分離する必要がある。なお、この見解は建築主事 の判断により異なる場合があるので、事前協議にて合意しておくことが重 要である。

10）利腕の左右を問わないよう、例えば A タイプ住戸と B タイプ住戸が反転 した関係となるよう間取りを構成した。 


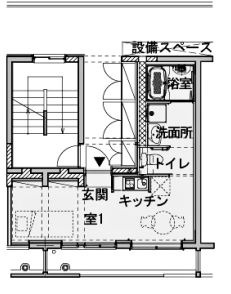

〈Aタイプ住戸 >

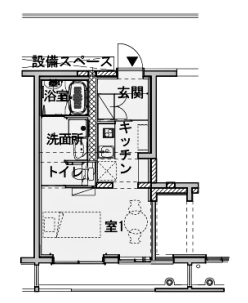

<Bタイプ住戸 >

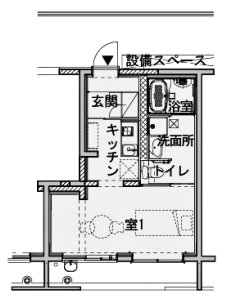

<Cタィプ住戸 >

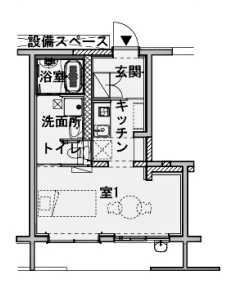

〈Dタイプ住戸>

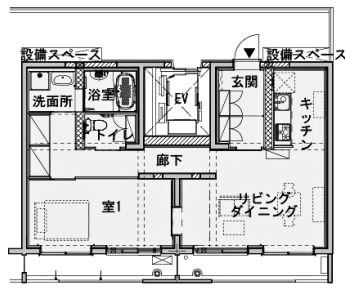

〈Eタイプ住戸>

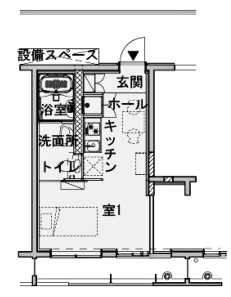

〈Fタイプ住戸>
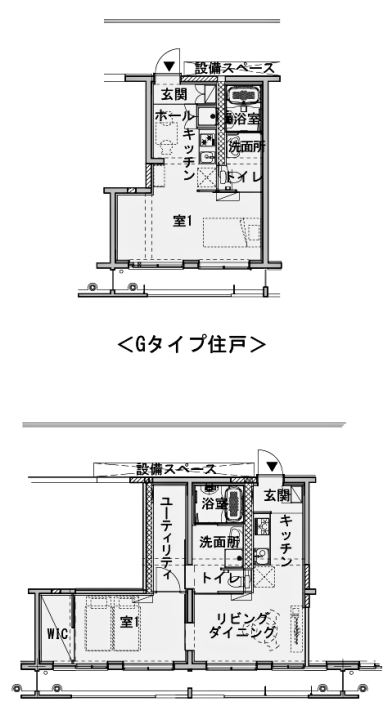

〈Hタイプ住戸>

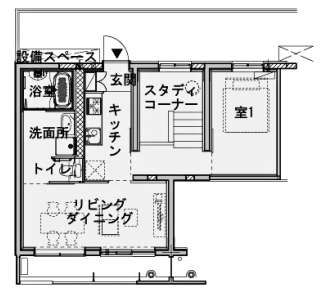

〈Iタイプ住戸 >

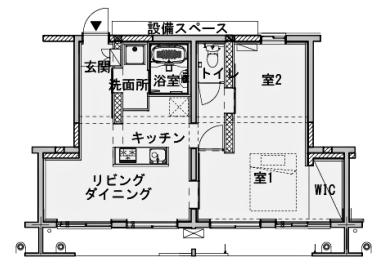

〈Jタイプ住戸〉

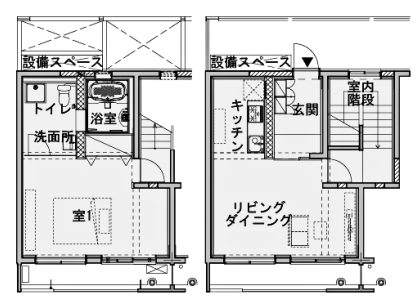

〈Kタイプ住戸>

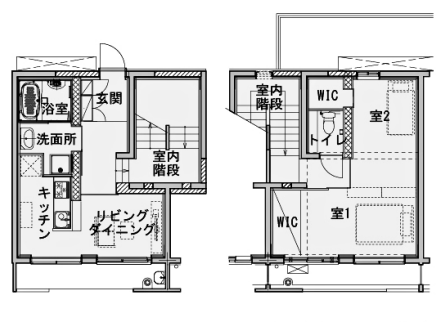

〈Lタイプ住戸>

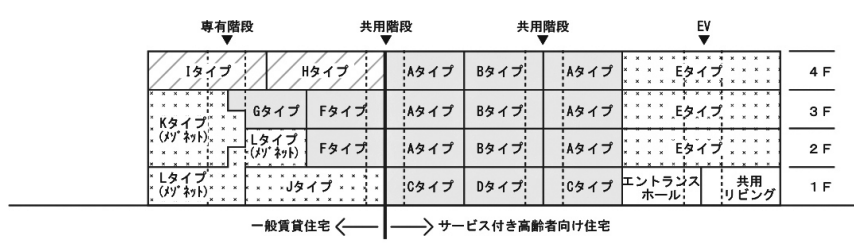

<ブロックプラン断面図>

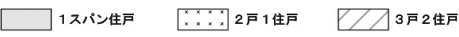
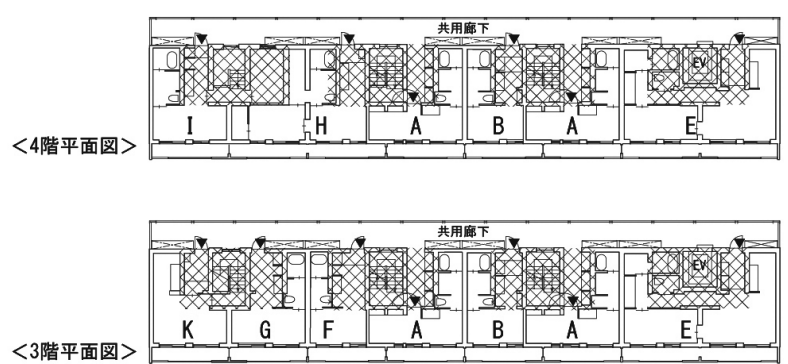

$<2$ 階平面図 $>$
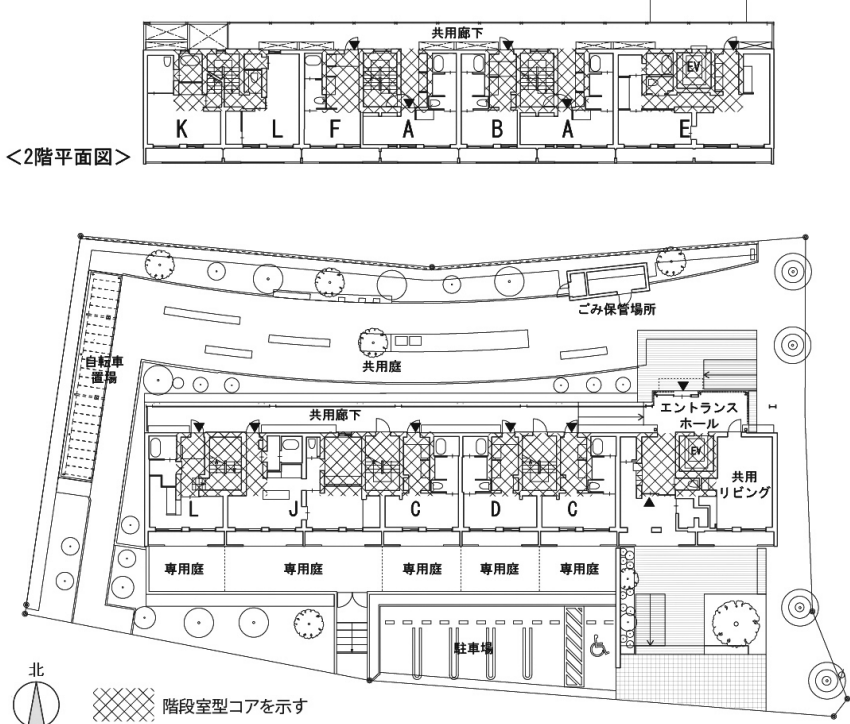

<配置図 兼1階平面图> 0

図 16 住棟平面図及びブロックプラン断面図

\section{参考文献}

1）社団法人 建築・設備維持保全推進協会：「公共住宅における大規模改修 事例集」, 社団法人 建築・設備維持保全推進協会報告書, 2003

2）辻 壽一、藤田 忍：「既設公的賃貸集合住宅におけるエレベーター設置 工事の考察 - 階段室型エレベーターを中心として - 」, 日本建築学会計 画系論文集 580 号, pp. 161-168，2004.6

3）小川 仁、深尾精一、他：「階段室型集合住宅へのエレベータ付加改修シ ステムの開発提案 - 階段室一体型エレベータの開発 その 1 - 」, 日本 建築学会技術報告集 第 26 号, pp. 715-720, 2007. 12

4）小川 仁、深尾精一、他：「階段室型集合住宅へのエレベータ付加改修シ ステムの開発提案 - 階段室一体型エレベータの開発 その 2 - 」, 日本 建築学会技術報告集 第 27 号, pp. 259-264, 2008. 6

5）山本一郎、中對浩之、他：「団地再生の取り組み - UR 都市再生機構のル ネッサンス計画について - (その 1) 〜 (その 4)」, 日本建築学会大会学 術講演梗概集 E-1 分冊, pp. 293-300, 2011.8

6）東京都供給公社、首都大学東京リーディングプロジェクトIIIリファイ ング建築開発プロジェクト研究チーム：「団地をリファイニングしよう。 烏山住宅リファイニングプロジェクト報告書」, 2014

[2015 年 2 月 17 日原稿受理 2015 年 4 月 27 日採用決定］

図 15 住戸バリエーションー覧 